\title{
العدد الرابع عشر \\ Satire and Social Reform in Sinclair Lewis's Novels Main Street and Babbitt
}

\author{
By \\ Asst. Prof. Adil Saleh Abd, Ph.D. \\ \& \\ Ahmed Abdul-Hussein Chiyad, M.A.
}

\begin{abstract}
$\underline{\text { ABSTRACT }}$
The present paper investigates the manners in which the American novelist Sinclair Lewis uses satire and social reform in his novels Main Street and Babbitt. It discusses how Lewis manipulates the techniques and tools and how he assumes the role of a social reformer. His target is the American society of early twentieth century and its dominant beliefs and values. Among the usual effective tools of satire Lewis uses are irony, sarcasm, comedy, mimicry, parody, and caricature.
\end{abstract}

In Main Street, Lewis vividly portrays the petty back-stabbers and hypocrites of a small town called Gopher Prairie with vicious realism and biting humor, thus undermining the romanticized view of small-town America during 1920s. His satire and social reform are directed in Babbitt towards the 
celebrated midsize industrial city considered by ambitious enterprising businessmen, civil boosters and self-made men a good place for success.

$$
\begin{aligned}
& \text { الهجاء والإصلاح الاجتماعي } \\
& \text { في روايتي سنكلير لويس الاجئ } \\
& \text { (الثارع الرئيس)() و (بابت)) (بنين) } \\
& \text { الأستاذ المساعد الدكتور عادل صالح عبد } \\
& \text { والسيد احمد عبد الحسين جياد (ماجستير) }
\end{aligned}
$$

\section{الخلاصة}

تستقصي الاراسة الحالية الطرائق والأساليب التي يتبعها الروائي الأميركي سنكلير لويس في هجائه للمجتمع الأميركي وقيمه ومعتقاته خلال بواكير القرن العشرين في روايتيه ((الثارع الرئيس)) و ((بابت))، وكيف يؤدي دور المصلح الاجتماعي من خلال هذا الهجاء، وذلك بتوظيفه أدوات الهجاء المعتادة الفاعلة كالمفارقة الساخرة والتهكم والكوميديا والمحاكاة الساخرة والمبالغة في رسم الثخصيات.

يوجه لويس هجاءه في رواية ((الشارع الرئيس)) نحو النمامين والمنافقين لبلاة صغيرة تدعى غوفر بريري بواقعية شديدة وسخرية لاذعة مقوضا بذلك النظرة الرومانسية التي كاتت تنظر بها كل بلدة أميركية صغيرة خلال عشرينيات القرن العشرين. اما في روايته الأخرى ((بابت)) فقد تناول بهجائه المدن الصناعية متوسطة الحجم التي كان رجال الأعمال والعصاميين وأصحاب الطموح ينظرون اليها بوصفها مكانا مناسبا لتحقيق ما يطحون اليه. 


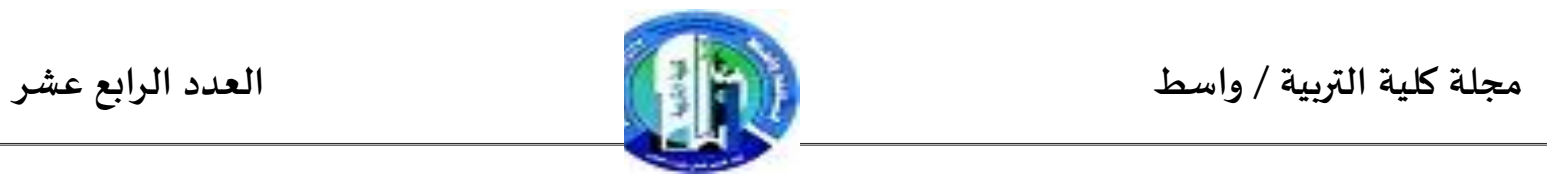

Satire and Social Reform in Sinclair Lewis's Novels Main Street and Babbitt

Sinclair Lewis is an American novelist, playwright, and social critic who gained popularity with satirical novels. The world of Sinclair Lewis "rests upon two observations: the standardization of manners in a business culture, and the stultification of morals under middle-class convention." ${ }^{1}$ Mark Schorer writes:

Lewis's familiarity with the manners of the small towns and cities, the real-estate developments and restricted residential areas, the small business men, the country doctors, the religious fakers, the clubwomen, the country officeholders, the village atheists and singletaxes, the school-teachers, librarians, the windbags of the lower income groups, the crazy professors and the maddened, hyperthyroid, high-pressure salesmenthe main types of middle-class and lower-middle-class provincial society, conspicuous now because he has identified them so thoroughly, all this gives his observations on apparent richness and variety. ${ }^{2}$

Critics agree on the fact that in most of his novels, Lewis is a satirist. They also seem to find him a satirist who uses his novels as a vehicle for social reform. One of the critics, Linda Laird Giedl, suggests, "as the first major satirist and social critic of the effects on ordinary middle-class men and women 
of the modern corporation, however, Lewis's place is surely secure." ${ }^{3}$ Anyhow, every social novelist must have the ability to see one's characters in all "their folly and self-absorption, from a detached point of viewand yet with cynicism kept always at bay by some tenderness and a little envy." ${ }^{4}$ In that respect, at least, he was a great social novelist, which is of course a much higher thing than a mere satirist. ${ }^{5}$

Lewis is a teller of long stories, a fabulist, and a legend-maker, who in his novels, originated national archetypes. In Lewis's derision, in his use of homely metaphors, in his technique of combining biting understatement with exaggeration, in his gift for comic mimicry, and in his passion for the monologue, proved typically American who sums up in his personality the characteristic American humour. ${ }^{6}$

Again, as a satirist, he had created a picture of America that "corresponds in a remarkable degree with the naïve caricature of America that all but the most enlightened and perceptive Europeans carry in their heads." ${ }^{6}$ Robert Cantwell writes that:

Sinclair Lewis has written the sharpest parodies of the lush, rococo, euphemistic sales-talk of American business life that we have, but he has also weighed down his novels with a heavy burden of unreal and exaggerated jargon, palmed off as common speech, with unfunny topical jokers, passed on as native 


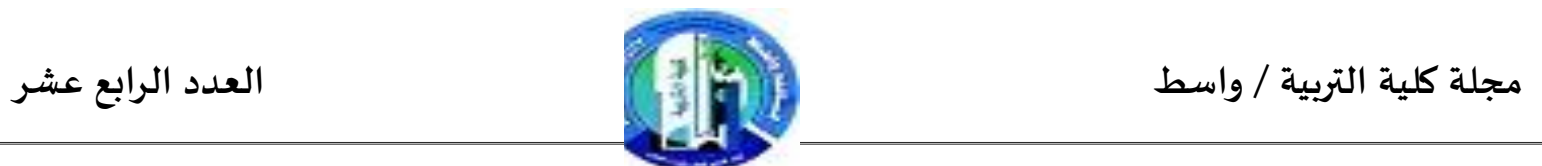

humour, and the weight of that dated mockery grows heavier every year. ${ }^{8}$

William B. Ober in "Arrowsmith and The Last Adam" suggests that Lewis was the most prominent American novelist of the day, writing at the peak of his powers who had achieved international fame for his attack on the provincial fabric of the daily life of average citizens in the American Midwest. ${ }^{9} \mathrm{He}$ described the failure of "the epic dream;" America had aspired to be a nation of free individuals, but the worship of material success by the many had forced the few independent spirits to turn their backs on their fellow men. ${ }^{10}$ Lewis always tried to portray the American society as it is for the purpose of satire and social reform. Mainly for the last reason, the popularity of Sinclair Lewis has been gained. ${ }^{11}$

Main Street is the story of a young girl, Carol Kennicott, who, having completed her study decides to change and develop a group of people according to her vision. Carol does the first step of her project when she gets married to William Kennicott, a doctor in Gopher Prairie, but she faces many obstacles on her way of improvement and social reform. Main Street is in the most customary and popular form of a novel and it carries the protest against the village to an immediate, immense audience. Lewis tries to portray the dilemma of Carol and the people in Gopher Prairie through his weapons of satire. ${ }^{12}$

Right from the beginning of the novel, Lewis's characters, especially Will and Carol Kennicott, are a complication in this novel, which may prevent it 
from being a satire. Unlike the one-dimensional characters typical of satire, the Kennicotts develop into somewhat rounded characters who demand attention and sympathy in their own rights. ${ }^{13}$ Carol in particular as the central figure of the novel, is developed more artistically than satirically as Lewis traces her development from a very naïve and foolishly idealistic young woman into a tolerant and understanding human being. But some critics on the other hand, have pointed out that they have observed in Main Street only Lewis the satirist and social critic. ${ }^{14}$

The first tool of satire in Main Street is caricature; for instance, Lewis presents Miles Bjornstam as a caricature figure in Gopher Prairie. He describes Miles as "the universal sign of winter" who

sneaked away from work to tell them, the children, improbable stories of sea-faring and horse trading and bears. The children's parents either laughed at him or hated him. He was the one democrat in town... Bjornstam could do anything with his hands solder a pan, weld an automobile spring, soothe a frightened filly, tinker a clock, carve a Gloucester schooner which magically went into a bottle. Now, for a week, he was commissioner general of Gopher Prairie. He was the only person besides the repairman at Sam Clark's who understood plumbing. Everybody begged him to look over the furnace and the water-pipes. He rushed from house to house till after bedtimeten o'clock. Icicles from burst water pipes hung along the 


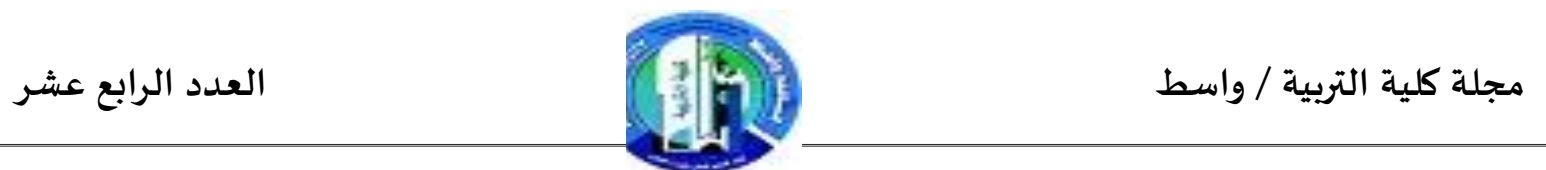

skirt of his brown dog skin overcoat; his plush cap, which he never took off in the house, was a pulp of ice and coal-dust; his red hands were cracked to rawness; he chewed the stub of a cigar.

Miles, "the Red Swede" as people name him for his moustache and socialist politics, becomes a guide to fulfilling beauty and freedom by remaining the village model of independence, as if he has a supernatural power to achieve the dreams of the Americans. Ironically, although he has neither the education nor the mood to be the model of Gopher Prairie, he represents the ideal of personal and social "pursuit of happiness". ${ }^{16}$

Not only is Miles a caricature figure but James Blausser is also presented as a type of a naïve person in Gopher Prairie who is not clever, merely "shrewd, but he likes to be called 'Honest Jim'. His satiric roots are suggested by his appearance; he reflects the gaudy world of confidence men." ${ }^{17}$ Lewis indicates the character of Blausser as a "bulky, gauche, noisy, humours man, with narrow eyes, a rustic complexion, and large red hands" (p. 413).

Lewis also supports his satire by presenting many scenes of irony, sometimes through dialogues and sometimes through soliloquies for instance, Miss Villets is supposed to be a librarian, but she is very proud of preventing people from reading the books in the library and keeping them very clean. She expresses her opinion about this idea: 


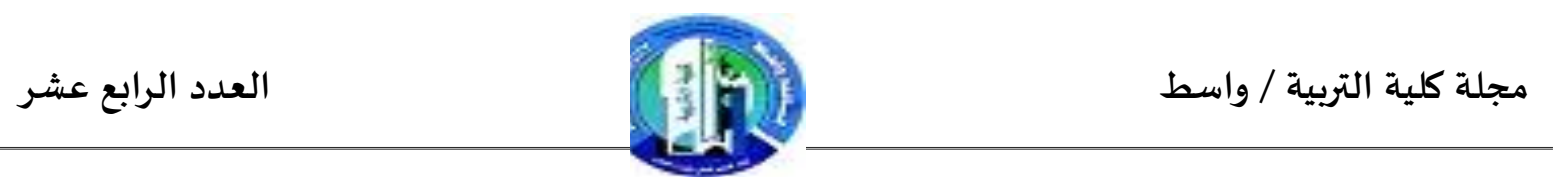

Nothing is cheaper than the minds of these children that come in and bother me simply because their mothers don't keep them home where they belong. Some librarians may choose to be so wishy-washy and turn their libraries into nursing-homes and kindergartens, but as long as I'm in charge, the Gopher Prairie library is going to be quiet and decent, and books well kept!

Lewis makes use of irony for many purposes. He uses it, for instance, as a defensive weapon on the part of Will for showing his attitude to democracy, money, life, death... etc. Carol, in rebellious anger, asks Will "precisely how do you expect these aliens to obey your law if the officer of the law teaches them to break it?" (p.419) Will's reply reveals Lewis's irony: "I suppose you'll be yapping about free speech next. Free speech! There's too much free speech and free gas and free love and all the rest of your damn mouthy freedom!" (p.420). Lewis's irony exposes unlawful and undemocratic suppression of free speech and the right to assembly during a war fought to uphold such democratic principles. $^{18}$

Irony is also clear in the conversation between Carol and Will about the character of Mr. Rauskukle who is "a land speculator whose wealth lofts him to the eminence of leading citizen of Shonstrom village." ${ }^{19}$ When Carol tells Will about the character of Mr. Rauskukle, and she is dissatisfied with this character, Will replies ,with naïve pride, and identifies Rauskukle as a person who is 
"worth three hundred thousands" and "owns lots of mortgages" (p.25). For Will, the true measure of human worth is money. The conversation continues and Carol again asks Will with "scarcely veiled irony why villagers and nearby farmers don't rise in anger to demand representation for Rauskukle's usurious suppression of independent people, as the mythic promise of the homestead." ${ }^{20}$ Ironically, Will's response is that they are not in need of this uprising as they enjoy liberty and happiness in Gopher Prairie although they are very poor and sometimes miserable.

In Main Street, Sinclair Lewis paints a picture of the difference between small town life, and urban sophistication by telling the story of a young educated city woman who marries a doctor and moves to a small town ${ }^{21}$. Moreover, Main Street is, as many critics believe, the best book Lewis ever wrote, because in it he achieved a compromise between the two viewpoints: that of Carol who is the one who wants to bring culture to Gopher Prairie and yet is snobbish, superior, and fanciful; and Dr. Kennicott, who is homely and goodnatured, dedicated but dull ${ }^{22}$. Carol rebels against the "unnecessary ugliness of Gopher Prairie and its smug stodginess". ${ }^{23}$ The girl is rebellious before she comes to this city. Always she puts plans for her life in a small city; for instance, she expresses her desire for reform and changing things in one of the key paragraphs of the book: 


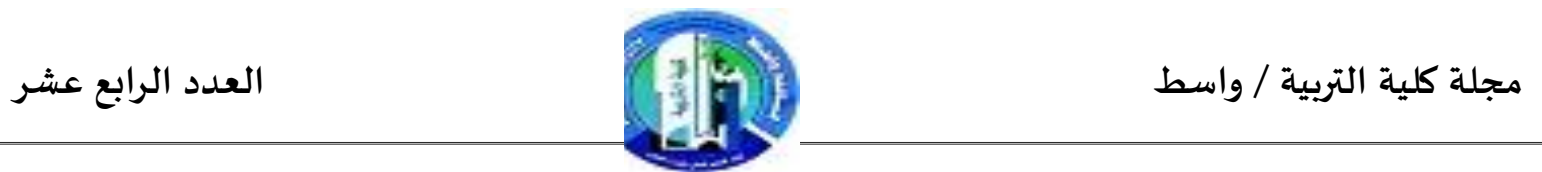

That's what I'll do after college! I'll get my hands on one of these prairie towns and make it beautiful. Be an inspirationI supposed I'd better become a teacher then, butI won't be that kind of a teacher. I won't drone. Why should they have all the garden suburbs on Long Island? No-body has done anything with the ugly towns here in the Northwest except hold revivals and build libraries to contain the Elsie books. I'll make 'em put in a village green, and darling cottages, and a quaint Main Street!

Carol Kennicott is sometimes a mouthpiece for Lewis himself. She expresses his idealism, his belief in democracy and freedom of speech, his sense of social justice, and his sympathy with the poor, the Swedish, German, and Norwegian farmers around Gopher Prairie. ${ }^{24}$ The characterization of Carol brings to mind Nora in Henrik Ibsen's (1828-1906) A Doll's House (1889), another classically conflicting woman of the age. Like Ibsen's play, Main Street poses universal problems and encourages the readers to look inward for the answers. It is a smart, subtle novel that invites a world of different reactions and interpretations. ${ }^{25}$ Carol tries to improve the manners of the people but, unfortunately, she is faced with many obstacles and problems. In addition, the people of Gopher Prairie resent her; they call her "crazy, flippant, foolish, snobbish, arrogant, silly, light woman, bad woman" and many other things. Carol sometimes wants to submit but at other times, she wants to continue in 
her struggle. At times, she is lazy, diligent, hopeless, hopeful, resigned, and rebellious and often lonely. ${ }^{26}$ Lewis depicts the rebellious twentieth century woman as a type whose revolt against the ugliness of village life reflects the new "spirit of that bewildered empire called the American Middle West" (p.8). Among the improvements, Carol suggests are:

a library board composed of the well read men of the town, and a campaign to renew interest in reading, (in a town where the great books are bypassed for the contemporary moralistic, optimistic, and religious authors), and a theater company containing one fine actor and a supporting cast of hams, who bungle through one play (the frivolous "Girl from Kankakee"; poor Carol and Shaw or Sophocles in mind. ${ }^{27}$

Furthermore, Carol's dream for the unlikely town of Gopher Prairie, in which the couple set up housekeeping, is to convert it to "a place of beauty, a project in town planning spawned by Carol's sociology reading in college." 28

Anyhow, Carol is a compelling figure because of the extraordinary tension between the eager expectancy of her hopes and the forces of dullness and smugness, which oppose her. Carol is shutt off from any meaningful chance to carry out her plans by her position as woman and wife, by her shallow education, by her own sentimentalism and flightiness, and by her sense of inadequacy to her monumental task; that is why she can bring her dreams to no real accomplishment. ${ }^{29}$ 
Lewis is dissatisfied with the behaviour of Gopher Prairie's citizens; that is why he presents these manners in a very detailed way. He describes the citizens who are bound by rigid conventions as

\begin{abstract}
gulping tasteless food, and sitting afterward thoughtless, in rocking-chairs bricklayers with inane decorations, listening to mechanical music, saying mechanical things about the excellence of Ford automobiles, and viewing themselves as the greatest race in the world.
\end{abstract}

In his description of the bad traditions of the people in America, He also narrates that:

The other tradition is that the significant features of all Villages are whiskers, iron dogs upon lawns, gold bricks, checkers, jars of gilded cat-tails, and shrewd comic old men who are known as "hicks" and who ejaculate "WaalI Swam." This altogether admirable tradition rules the vaudeville stage, facetious illustrates, and syndicated newspaper humour, but out of actual life it passed forty years ago. Carol's small town thinks not in hoss-swapping but in cheap motor cars, telephones, ready-made clothes, silos, alfalfa, kodaks, phonographs, leather-upholstered Morris chairs, bridge-prizes, oil-stocks, motion-pictures, land-deals, unread sets of Mark Twain, and a chaste version of national politics. 


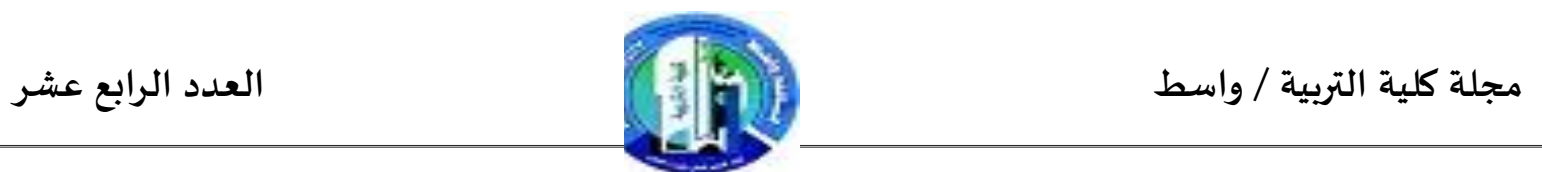

Otherwise, Carol and Will Kennicott are "triumphs of the national normalcy-she with her vague stirrings, her unintelligible yearnings, her clumsy gropings," 30 and he with his "magnificent obtuseness, his childish belief in meaningless phrases, his intellectual deafness and near-sightedness, his pathetic inability to comprehend the turmoil that goes on within her." ${ }^{31}$ Here is the tragedy of American life: "the disparate cultural development of male and female, the great strangeness" ${ }^{32}$ that lies between husband and wife when they begin to function as members of society.

Lewis, especially in the character of Will Kennicott, tries to explain the naivety of the educated people in America because Will, like his Main Street friends, has an uncritical mind. Will's world is composed equally of "medicine, land, investment, Carol, motoring, and hunting" (p.195). For Will, life holds neither uncertainty nor discriminating choices. He thus lives with "awesome complacency in the harsh, acquisitive culture of an early twentieth-century small town assuming the unconscious and at times tyrannical ignorance of his peers as his reality. ${ }^{33}$ Although "heroic as a country doctor who braves prairie winters in a horse-drawn sleigh at all hours to care for the immigrant farm families, he is essentially an obtuse individual, practical but inarticulate." ${ }^{34}$ When "a land boom occurs his uncritical mind accepts blind fortune as personal destiny; unable in this respect to perceive a communal or cultural failure in his financial success. ${ }^{35}$ Lewis is explicit: 


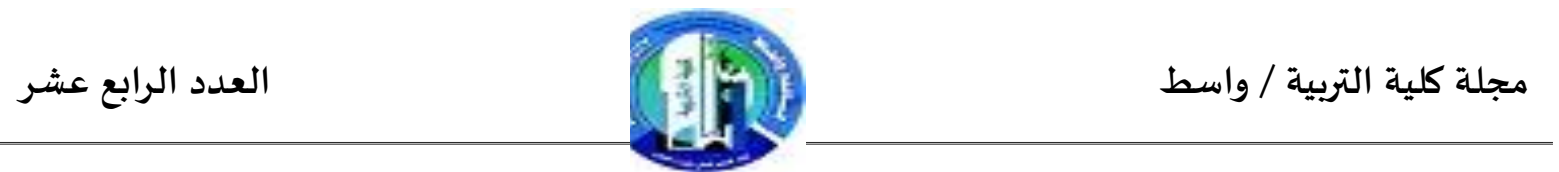

The wheat money did not remain in the pockets of the farmers; the town existed to take care of all that Iowa farmers were selling their land at four hundred dollars an acre and coming into Minnesota. But whoever bought or sold or mortgaged, the townsmen invited themselves to the feast-millers, real-estate men, lawyers, merchants and Dr. Will Kennicott. They bought land at a hundred and fifty, sold it next day at a hundred and seventy, and bought again.

(p. 397)

James Marshall, in "Pioneers of Main Street" states that Main Street is "a re-working in dramatic form of the individual's responses to the collective will of society." ${ }^{36}$ This response is usually "envisioned, so to speak, as a drama of human dissociation in which the human individual stubbornly seeks to maintain his individuality through rebellion and struggle against the confining cultural forces operative in his/her society." ${ }^{37}$

At the end of the novel, Carol remains a frustrated figure living under a "self-imposed truce in a community which she might have transformed into something distinctive and beautiful;" ${ }^{38}$ Carol addresses Will pointing to her sleeping daughter:

Do you see that object on the pillow? Do you know what it is? It's a bomb up smugness. If you Tories were wise, you wouldn't arrest anarchists; you'd arrest all these 


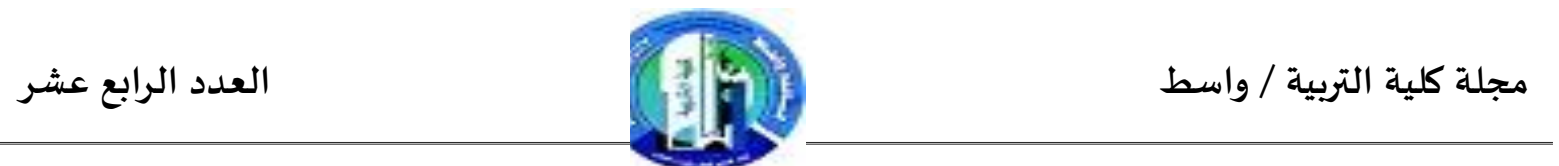

children while they're sleep in their cribs. Think what that baby will see and meddle with before she dies in the year 2000! She may see an industrial union of the whole world, she may see aeroplanes going to Mars. (p. 432)

Meanwhile there is a hope in change and development but not now; may be "in the year 2000". Lewis ends his novel with this scene to give a glimpse of hope for a better society in the next generation. Although he attacks different types of people with the harsh weapon of satire, he presents a life in the middle of death at the end of Main Street. Eventually, Carol is still a rebel, though now "somewhat tamed, and her attitude lets us continue to like and respect her because she has not sold out, and because she does not praise what she has formerly battled with." ${ }^{39}$

Babbitt is a novel which shows a cross section of American middle class life through the eyes of the conformist, George F. Babbitt. In addition, it depicts the complacency and materialism of the protagonist a real-estate agent and representative middle-class family man from Zenith, a Midwestern city. He tries to spite convention, conformity, and smugness of middle class life by pursuing liberalism and freedom of passion, but he soon finds the price of nonconformity too great and resigns himself to conventions. Finally, he hopes that his son might challenge the forces he himself has compromised with. This novel criticizes bourgeois materialism and satirizes the standardization and conformity 
of life in a business culture and the suppression of liberty under the burden of middle class customs. ${ }^{40}$

Irony, as an effective weapon of satire, is the tool Lewis begins with in Babbitt; for instance, Babbitt and many of his acquaintances call the immigrants and minorities in Zenith as bigots. The irony of this subject in the book is that although men of Babbitt's stature openly shared and joked with one another about their superiority to all other races, no one would ever admit that he is even by a small degree a bigot. ${ }^{41}$

Ironically, Babbitt begins with the description of a modern city; a city for "giants". The remainder of the novel provides an "extended ironic commentary on this statement, as it demonstrates how Babbitt and the others of his kind who live in this city are pygmies, not giants." ${ }^{42}$ Furthermore, the opening lines of Chapter Three state the truth of Babbitt's life:

To George F. Babbitt, as to most prosperous citizens of Zenith, his motor car was poetry and tragedy, love and heroism. The office was his pirate ship but the car his perilous excursion ashore.

Here, Lewis employs irony to show how interested Babbitt is in his car. The simple act of driving or gassing it becomes a ritual more important than church, work or anything else. It also shows how "excited Babbitt gets wherever 
he drives. Working on a pirate ship would be fairly monotonous, but all onshore excursions would be exciting and perilous." ${ }^{44}$

Another scene of irony is when Babbitt is proud of the furniture of his house:
An altogether royal bathroom or porcelain and glazed tile and metal sleek as silver. The towel-rack was a rod of clear glass set in nickel. The tub was long enough for a Prussian Guard, and above the set bowel was a sensational exhibit of tooth-brush holder, shaving-brush holder, soap-dish, sponge-dish, and medicine-cabinet, so glittering and so ingenious that they resembled an electrical instrument-board.

Ironically, this house becomes a dull house for Babbitt and he escapes with his friend, Riesling, to another town to entertain himself and forget the agony of his life. Lewis, here, tries to make the readers make fun of Babbitt and his friends because decoration and furniture are not as important as the happiness of the human being. Lewis also satirizes the amassment of objects and possessions as a cultural norm. ${ }^{45}$

Furthermore, it is funny how Babbitt is, when he buys the silver lighter for his car. He feels so important and self-righteous. Sadly, that feeling is cut short when he realizes that he has just decided to quit smoking earlier that morning. It is even funnier when he decides not to quit and taper-off, so that he can show off his lighter to all the people in his town. ${ }^{46}$ 


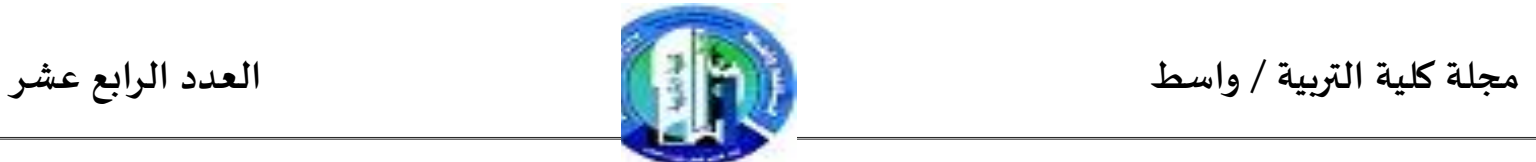

Becoming more confident of his purposes, Lewis broadens the caricature of Babbitt and becomes even savage in his attacks upon the dominant American idols. Babbitt, the realtor, is not a man; he is assembled out of many actual Babbitts. The effect is at once lifelike and weird. As with an almost perfect scarecrow the thing is so much like life that it nearly lives. ${ }^{47}$ In addition, it is like "an anatomical model of an average man, a purely theoretical concept which has no actual existence. For in any living man the average qualities are always found in some unique combination. ${ }^{48}$ Furthermore, Lewis Mumford suggests that Babbitt is:

A weak figure, a ridiculous figure, caught in a civilization whose very virtues, hygiene and mechanical efficiency were, by their divorce from any complete conception of a humane life, as inimical to development as the dirt and inefficiency of other culture-that was Babbitt that was his country! ${ }^{49}$

Lewis designed Babbitt to be an example of his class. He is the common man; the self-made businessman. He is the kind of man that would not ask for directions from his wife. ${ }^{50}$ Babbitt is the lover of "gadgetry and automobiles; the smoker of fine cigars, the conservative Republican; the loyal taxpayer, the supporter of the troops, and the anti-communist. In short, he is the man in the middle who makes it all happen."

Another example of caricature is T. Chumley Frink who is one of Babbitt's friends and associates. He is considered a poetic genius; all the people respect 
him for the sake of his poetry and creativity but actually, he writes clumsy, terrible jingles for advertisements. ${ }^{52}$ This is a sample of his writing:

If I should look around and buzz, and wonder in what town I was, I swear that I could never tell! For all the crowd would be so well, in just the same fine sort of jeans they wear at home and dull the fellows standing round and a-talkin always, I'll be bound, the same good jolly kind of gruff' that Nice Guys talk in my home town!

However, he is secretly unhappy that he never fulfills his youthful ambitions to be a real poet; on the other hand, he betrays his talent.

Whereas Main Street has signaled a necessary revolt against the ingrown values of the village, Babbitt demonstrates that these values prevailed in cities as well as country towns. ${ }^{53}$ The protagonist of the novel is "a well-meaning, clubbable, but far from perfect man, internally torn between a troubled, barely understood craving for romance or spiritual nourishment and the ever impinging demands of pragmatic reality" ${ }^{54}$ :

In twenty-three years of married life he had peered uneasily at every graceful ankle, every soft shoulder; in thought he had treasured them; but not once had he hazarded respectability by adventuring. Now, as he calculated the cost of repapering the Styles house, he was restless again, discontented about nothing and everything, ashamed of his discontentment, and lonely for the fairy girl. 


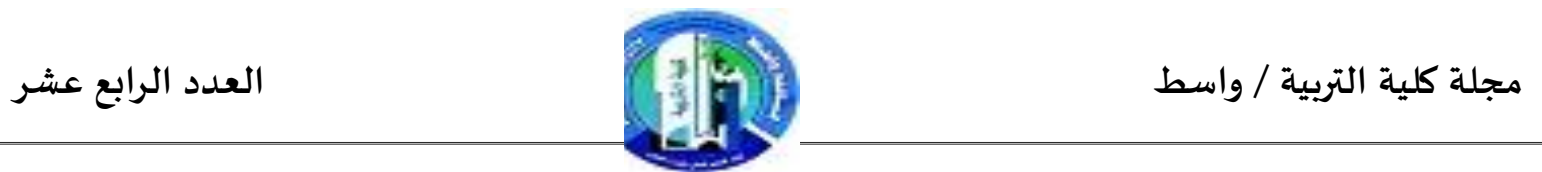

The only beauty and magic left in his life are the visitations of an elusive dream girl. Lewis writes:

Babbitt was again dreaming of the fairy child, a dream more romantic than scarlet pagodas by a silver sea. For years, the fairy child had come to him. Where others saw but George Babbitt, she discerned gallant youth. She waited for him, in the darkness beyond mysterious groves, when at last he could slip away from the crowded house he darted to her. His wife, his clamoring friends, sought to follow, but he escaped, the girl fleet beside him, and they crouched together on a shadowy hillside.

(pp. 2-3)

Like Babbitt, the other inhabitants of this purgatory try to resolve or forget their inner torment and agony by arranging a busy and gimmick-filled outer world, by their frenetic pursuit of money, by the chase to acquire class and caste symbolsa chase so exhausting that no energy remains to enjoy what has been achieved. Their symbols become ends in themselves. In such a world, Lewis portrays an individual revolt but it comes too late for Babbitt; he could see himself clearly for the first time at forty-eight and make changes in his life. Babbitt is a symbol of the American society. ${ }^{55}$ H. L. Mencken analyzes the American society as follows:

Wealth symbolizes honor and prestige in modern society; it is necessary for acceptance by our fellows. For status 


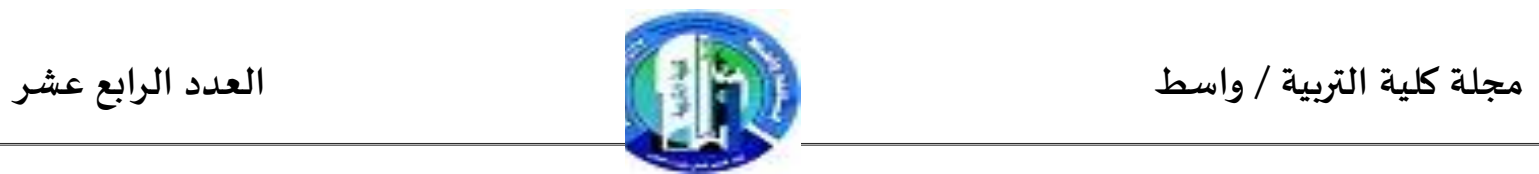

we need money and without that status there can be no self-respect. Yet once we accumulate a certain sum, it is not enough. We are driven ever to increase what we own, to rise as far above the average as we can. Moreover, money brings power, or the sense of power; and, since man's striving for money also springs from his sense of purposeful activitywhat Veblen calls "the instinct of workmanship"we have come to see success by money. But the possession of money is not alone sufficient to satisfy man; he must demonstrate his wealth, either by his own freedom from labor or by the amount of goods and services he and his family consume. Since money becomes the biggest thing, and the surest way in a business society to success and power, the aim of business is to gain money; all is subordinated to profit, even if the profit is gained at the community's loss. Nor are profit and wages necessarily related to true value. ${ }^{56}$

Ironically, the word Zenith means "peak or epitome"; this 1920's city seems bursting with new opportunity for the optimistic and prosperous middleclass of the era. The people of Zenith believe that it is the epitome of the era, the perfection of technology, industry, agriculture, trade, all the things that make a city great. ${ }^{57}$ For the people of Zenith their city is the perfect example of the greatness of the decade but the progress of the novel indicates what kind of city Zenith is;

At that moment in Zenith, three hundred and forty or fifty thousand ordinary people were asleep, a vast unpene- 


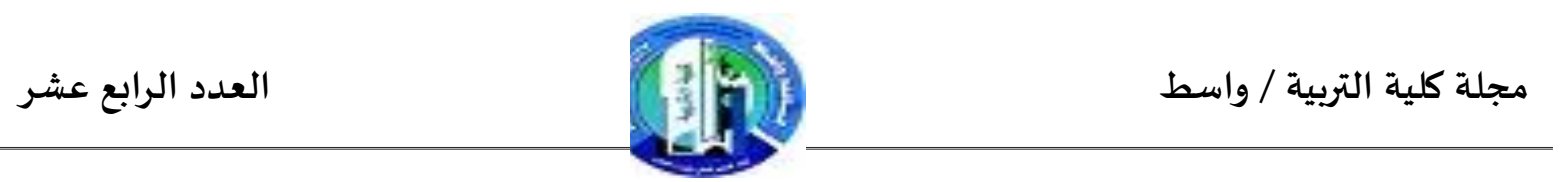

trated shadows. In the slum beyond the railroad tracks, a young man who for six months had sought work turned on the gas and killed himself and his wife. At that moment Lloyd Mallam, the poet, owner of the Hafiz Book Shop, was finishing a rondeau to show how diverting was life amid the feuds of medieval Florence, but how dull it was in so obvious a place as Zenith.

Business not only influenced academia, but also touched religion. Lewis suggests that many inhabitants who are interested in the church are not religious but they join temples and churches only for the sake of membership and business connections. Babbitt, for instance, certainly does not attend services for their spiritual message, but because he wants to be seen as a moral citizen. ${ }^{58}$ Lewis writes:

If you had asked Babbitt what his religion was, he would have answered in sonorous Boosters'-club rhetoric, "My religion is to serve my fellow men, to honor my brother as myself, and to do my bit to make life happier for one and all." If you had pressed him for more detail, he would have announced, "I'm a member of the Presbyterian Church, and naturally, I accept its doctrines." If you had been so brutal as to go on, he would have protested, "There's no use discussing and arguing about religion; it just stirs up bad feeling." 
In short, Lewis argues that even spirituality has been commercialized and standardized. In Babbitt, Lewis gives his own impression of "the new hectic American capitalist life. It is important to recognize this impression as nightmarish." ${ }^{59}$ Meanwhile, there is "the incessant bustle of Zenith, the Zip city, with its office towers and automobiles and golf courses and gadgets;" ${ }^{60}$ there are Babbitt and his fellow businessmen continuously growing richer or hoping to grow richer. In fact, the Zenith scene is demonic. It is a world not only of nonart and non-culture, but also of non-security and non-love. In other words, the struggle described by Lewis in Babbitt presents a demonic American society from which there is no escape, and, on the other side, "a hero whose solitariness is complete." 61

Babbitt portrays the convention of life in 1920's. Lewis precisely "evokes the conformity and orthodox life styles that shaped a growing culture." ${ }^{62} \mathrm{He}$ explains the constraints of convention that plagued George Babbitt, and mocks society as a whole for its lack of liberal views. Babbitt throughout the novel seems to be trapped in a maze, and is told by the machine when to turn. ${ }^{63}$ The tragedy of George Babbitt lies in the fact that "the pathetic and overwhelming defeat administered his vague idealism by the forces of organized Zenith." ${ }^{64}$

In Babbitt, the novelist tries to portray the spiritual malady which afflicts Zenith. That malady is fully analyzed in the person of Babbitt himself. ${ }^{65}$ Babbitt feels "vague longings which cannot be satisfied by the mechanical toys which are his substitutes for joy and passion and wisdom; his symbols of truth and 
beauty, and there is in him a wish for something beyond even electric cigar lighters." ${ }^{66}$ Babbitt discovers that he has tendencies toward vice which he has neglectedbut not wholly; as he approaches fifty, he hastens to make up for the neglect. He enters an irregular relationship and joins "a frivolous gang of youths, in which he plays the role of a generous sugar daddy" ${ }^{67}$; but his deeds find him out.

Critics see in Babbitt a proof that the typical American was like a standard part of a machine, always ready to be fitted into the national design. ${ }^{68}$ Babbitt says much the same thing before lunch, during lunch, after lunch, even in the evening. To his friend Paul Riesling he complains:

I don't know what's the matter with me to-day. Kind of comes over me: here I've pretty much done all the things I ought to; supported my family, and got a good house and a six-cylinder car, and built up a nice little business, and I haven't any vices 'specially, except smoking. I belong to the church, and play enough golf to keep in trim, and I only associate with good decent fellows. And yet, even so, I don't know that I'm entirely satisfied!"

(pp. 60-1)

In this little speech, there is what is called the essential insight of the book. Lewis presents the Babbitt-vision of the American Dream. Babbitt lives according to its inspiration, but it is a dream that leaves the dreamer restless and 
betrayed. ${ }^{69}$ Finally, Lewis achieves the full effect, which he was aiming at. He shows the tragic downfall of a generation "too consumed in their own egos to ever realize what is going on around them. ${ }^{70}$ The effect of Babbitt made the public realize what the American middle class was like in 1920's and how they eventually lost everything. ${ }^{71}$ 


\section{Notes}

${ }^{1}$ Mark Schorer, "Sinclair Lewis and the Method of Half-Truth" in Sinclair Lewis: A Collection of Critical Essays, ed. Mark Schorer (Englewood Cliffs, N. J.: Prentice-Hall, Inc., 1962), p.49.

${ }^{2}$ Ibid., p. 50.

${ }^{3}$ Linda Laird Giedle, "Lewis's Early Fiction Still Resonates Today" The Sinclair Lewis Society Newsletter 6 (Spring 1997), p. 14.

${ }^{4}$ William Kraemer, "Dr. Lewis and Homeopathy" The Sinclair Lewis Society Newsletter 11 (Autumn, 2000) : p. 15.

${ }^{5}$ Although Sinclair Lewis is known as a satirist, he was not only interested in people but also nature, and described its traces in many of his novels. In his Free Air, The God Seeker, and Mantrap his attitude toward nature is pastoral. He also contrasts nature with civilization and praised the beauty of nature as in William Wordsworth's poems.

${ }^{6}$ Sheldon Norman Grebstein, Sinclair Lewis (New York: Twayne Publishers, 1962), p.30.

${ }^{7}$ Lewis Mumford, "The America of Sinclair Lewis" in Sinclair Lewis: A Collection of Critical Essays, p.106.

${ }^{8}$ Robert Cantwell, "Sinclair" in Ibid., p.111.

9 William B. Ober, M.D., "Arrowsmith and The Last Adam" in Interpretations of "Arrowsmith": A Collection of Critical Essays, ed. Robert J. Griffin ( Englewood Cliffs, N. J.: Prentice-Hall, Inc., 1968), p.57.

${ }^{10}$ D.J. Dooley "Arrowsmith" in Ibid., p.64. 
11 One of the most superior accomplishments of Lewis was that he was the first American to receive the Nobel Prize for Literature. This event made Lewis well known nationally. Before he died, he sold over two million copies of Main Street alone. Furthermore, Lewis lived and wrote during the time of the Feminist Movement at end of World War I. Lewis wrote about the positives and the negatives of the times. (Sheldon Norman Grebstein, p. 114).

${ }^{12}$ Carl Van Doren, "Sinclair Lewis and the Revolt from the Village" in A Collection of Critical Essays, p.84.

${ }^{13}$ Clare Virginia Eby "Extremely Married: Marriage as Experience and Institution in the Job, Main Street, and Babbitt" in File://A: \l filelPm (3).htm. Google. Com. 8/9/2005.

${ }^{14}$ Grebstein, p. 67.

${ }^{15}$ Sinclair Lewis, Main Street, e. d. Mark Schorer (New York: The New American Library of World Literature, Inc, 1962), p.83. All subsequent references to the novel are to this edition, referred to by page numbers.

${ }^{16}$ James Marshall, "Pioneers of Main Street" Modern Fiction Studies31(Autumn 1985): 535.

${ }^{17}$ Ibid., p. 536.

${ }^{18}$ T. K. Whipple "Sinclair Lewis" in Sinclair Lewis: A Collection of Critical Essays, p.78.

${ }^{19}$ Ibid., p. 87.

${ }^{20}$ Marshall, p. 539.

${ }^{21}$ Ibid., p. 540.

${ }^{22}$ H. L. Mencken, "Portrait of an American Citizen" in Sinclair Lewis: A Collection of Critical Essays, p. 20.

${ }^{23}$ Gore Vida, "The Romance of Sinclair Lewis" in File://A: $\backslash$ A Literary History of the American West. htm. Google. Com. 12/4/2006. p. 8. 
${ }^{24}$ Giedle, p. 14.

${ }^{25}$ Carolyn Petrie, "Main Street Invites Interpretations: Theatre Review" The Sinclair Lewis Society Newsletter 12 (Spring 2003), p. 9.

${ }^{26}$ Eby, pp. 6-7.

${ }^{27}$ Marshall, p. 536.

${ }^{28}$ Vida, p. 9.

${ }^{29}$ Ibid., p. 2.

${ }^{30}$ Ibid., p. 6.

31 Ibid., p. 3.

${ }^{32}$ Ibid., p. 6

${ }^{33}$ Mencken, p. 18.

${ }^{34}$ Geoffrey Moore, "Sinclair Lewis: A Lost Romantic" in Sinclair Lewis: A Collection of Critical Essays, pp. 158-9.

${ }^{35}$ Marshall, p. 539.

${ }^{36}$ Ibid., p. 547.

${ }^{37}$ Grebstein, p. 66.

${ }^{38}$ Ibid., p.67.

${ }^{39}$ Ibid., p. 68.

${ }^{40}$ Lucy Zhang, "Standardization and Conformity: A Critical Study of Sinclair Lewis's Babbitt" The Sinclair Lewis Society Newsletter 10 (Fall 2001), p. 7.

${ }^{41}$ Vida, p. 4.

${ }^{42}$ Ibid., p. 5.

${ }^{43}$ Sinclair Lewis, Babbitt, ed. Mark Schorer (New York: Harcourt, Brace\& World, Inc., 1950). p.24. All subsequent references to the novel are to this edition, referred to by page numbers.

${ }^{44}$ Marshall, p. 545. 
45 Paul Vincent Mclnnes, "Sinclair Lewis and Bret-Easton Ellis" The Sinclair Lewis Society Newsletter 13 (Spring 2001), p. 4.

${ }^{46}$ Marshall, pp. 545-6.

${ }^{47}$ Grebstein, p. 70.

${ }^{48}$ Mumford, p. 103.

49 Walter Lippmann, "Sinclair Lewis" in Sinclair Lewis: A Collection of Critical Essays, p.85.

${ }^{50}$ Rebecca West "Sinclair Lewis Introduces Elmer Gantry" in Ibid., p.40.

${ }^{51}$ Vida, p. 2.

${ }^{52}$ Zhang, p. 19.

${ }^{53}$ Lippmann, p. 8.

${ }^{54}$ Robert J. Griffin "Introduction" in Interpretations of "Arrowsmith": A Collection of Critical Essays, p.8.

${ }^{55}$ Zhang, p. 21.

${ }^{56}$ H. L. Mencken, "Portrait of an American Citizen" in Sinclair Lewis: A Collection of Critical Essays, pp. 20-2.

${ }^{57}$ Eby, p. 7.

${ }^{58}$ Zhang, p. 17.

${ }^{59}$ T. R. Fyvel "Martin Arrowsmith and His Habitat" in Interpretations of "Arrowsmith": A Collection of Critical Essays, p. 95.

${ }^{60}$ Ibid., p. 95.

${ }^{61}$ Ibid., p. 96.

62 Ibid., p. 96.

${ }^{63}$ Vida, p. 6.

${ }^{64}$ Ibid., p. 7. 
${ }^{65}$ See Sally E. Parry, "Iron George: Myths of Masculinity in Sinclair Lewis's Babbitt and Mantrap". The Sinclair Lewis Society Newsletter. 6 (Spring,1997.pp. 31-35 and Leon Howard, Literature and the American Tradition(New York: Doubleday \& Company, Inc., 1960), pp. 266-285.

${ }^{66}$ T. k. Whipple "Sinclair Lewis" in Sinclair Lewis: A Collection of Critical Essays, p.75.
${ }^{67}$ Ibid., p. 79.
${ }^{68}$ Lippmann, p. 86.
${ }^{69}$ Zhang, p. 17.
${ }^{70}$ Vida, p. 8.
${ }^{71}$ Ibid., p. 7. 